\title{
TISCHNER'S TAKE ON EVIL ON THE EXAMPLE OF THE CHEKIST BY ALEKSANDR ROGOZHKIN
}

\begin{abstract}
The problem of evil is unavoidable and largely incomprehensible, and it is exactly for that reason that it is of great importance for our being. This aspect of Tischner's philosophy can be successfully shown using the example of Andrei Srubov, the protagonist of The Chekist. By looking at Tischner's agathology we receive hope that we are not doomed to be defeated by evil within our lifetime. What seems to be crucial in opposing evil is the realization that there is always a decision to be made.
\end{abstract}

Keywords: Tischner, Rogozhkin, evil, Communism, mystery.

But is it even the case that while having participated in evil - in something that we do not want - we really are that which we know we are? If our participation goes beyond the borders of our consciousness, that means that truly everything might be different.

J. Tischner, Spór o istnienie czlowieka

\section{Introduction}

The thesis of this article is that Tischner has become skeptical about the capabilities of modern philosophy exactly when he found out that it is helpless in the face of totalitarianism. Philosophy is useless if it pretends to know a solution to any given problem. We, the readers, are faced here with skepticism towards the capabilities of a man in overcoming evil. It is men that make philosophy, and the first problem with evil is that it cannot be fully grasped (if you do not see it, you cannot overcome it). It cannot be fully grasped because evil, as evil, avoids being noticed. Therefore, one has to decide from the beginning if he wants to be good or not by making a sacrifice from his life. If he does not, the cunning evil can always make use of his indecisiveness, which we will see in concrete examples.

•Address for correspondence: Dąbrówki 19C/28, 44-210 Rybnik, Poland. Email: a.jochlik@us.edu.pl. 
The shortcoming of such a philosophical approach is that it is abundant with examples, but not conceptualized enough. It could not be, for to overconceptualize a mystery is to pretend that it is a problem that requires the right configuration of the proper concepts ${ }^{1}$; it is to pretend that we know directly what the essence of it is ${ }^{2}$, whereas we really are just in the search for guidance in our life ${ }^{3}$. Here the guide is telling us that authentic evil requires, in order to work, a consistent will to action which instrumentally uses the lack of such will in others (i.e. which uses the naïveté and fears of others), where the means of that usage (the bait) are the values commonly associated with being something good. The subject (the bearer) of such evil is unknown to us, though it often seems that it is an idea, like revolution talked about by others as if a revolution was a person. For that reason, the subject of evil is called by Tischner a spectre (zjawa). One knows what it wants rather than what it is ${ }^{4}$.

\section{To see a world that is not yet broken - the husbandman}

Tischner focuses his attention on the evil of Communism ${ }^{5}$. Tischner looks at Communism from the perspective of an evil that is growing from the inside of a man, especially during dialogue. That dialogue is the prelude for the inner monologue of he who hates, and, while hating, he is about to act accordingly to his inner self. Now, this has a lot to do with the mystery of evil because it seems from the tragic history of the $20^{\text {th }}$ century that the inner self is not necessarily something that makes a man of goodwill ${ }^{6}$.

I would like to explain this aspect of evil, this malice-from-within that gives terrible examples to others, but to do so, we first need to know what Tischner associates with the Good. What is good, though not heavenly, lies in the past, in the Middle Ages ${ }^{7}$. The key to understanding the Good lies within how we view human labour. Naturally, this world of ours is not, and will never be (not without God's intervention) a paradise. This is a place of constant struggle for survival. We cannot change that. What we can do is to make sure that this world, full of sweat and tears, will not become more of a burden than it needs to be. That way the fear for survival will not make us numb and blind, i.e. it will not become the fear of the other. This harsh struggle, the life itself, is not so much of a burden if the working man still feels that he is $a$ man while he works ${ }^{8}$. To illustrate that, Tischner gives us an

\footnotetext{
${ }^{1}$ See G. Marcel, Homo Viator, p. 207 \& J. Benefield, The Place of God ..., p. 58.

${ }^{2}$ See G. Marcel, Homo Viator, p. 151.

${ }^{3}$ See G. Marcel, Homo Viator, pp. 9-10, p. 19, p. 119 \& pp. 136-142, G. Marcel, The Mystery of Being, pp. 1-4, p. 13, pp. 57-58 \& B. Treanor, Aspects of Alterity ..., p. 53.

${ }^{4}$ See J. Tischner, Filozofia dramatu, p. 186 \& J. Tischner, Spór o istnienie czlowieka, p. 350.

${ }^{5}$ See J. Tischner, Spór o istnienie czlowieka, p. 41.

${ }^{6}$ See J. Tischner, Spowiedź rewolucjonisty ..., p. 85.

${ }^{7}$ See J. Tischner, Spór o istnienie czlowieka, p. 12. I am fully aware that this point is valid only within the context of Etyka solidarności, not within the context of the earlier period where Tischner defends modernity against the Thomists.

${ }^{8}$ See J. Tischner, Etyka solidarności oraz Homo Sovieticus, pp. 25-29.
} 
example of the husbandman (gospodarz, which means a host of the house and a peasant - so, simply speaking, a peasant who has his dignity):

The old Polish word "husbandman" shows a man who has tied his fate to the land [ziemia] - with the work on the soil [rola]. So it links the husbandman with a homestead [gospodarstwo]. A homestead is a territory that has been tamed by the labour of the husbandman - i.e. husbandry [gospodarowanie]. The meaning of all these words is deeply rooted in our history. Poland was first and foremost a country of husbandmen. Husbandry - the husbandman's labour - was the oldest Polish labour, and Poland the oldest homestead. He who is willing to delve deeper into the history hidden behind these meanings will come across their common source - the ethos of people whose duty was to serve Life. These people, while serving Life itself, gained something from Life's wisdom. In our tradition it was never the case that husbandry of land was viewed as an expression of concern for just the self-interest of the husbandman. If someone did not understand that, he brought shame upon himself. Husbandry was a service, and where there is a service, there is a living experience of the community's law. We take pride in the fact that during the religious wars our country was a country of tolerance. I think we could also take pride in the fact that in our country there was no hunger like a plague on a massive scale [...]. The disaster of starvation was something extraordinary, caused by the whims of nature rather than human egoism. The concern of a husbandman is not only the concern for the land but also for all the homestead, especially for the home. Home is the heart of and reason for the homestead. [...] The rocks, the trees, the soil, and everything that constituted husbandry was one, big act of pointing [wskazanie] towards people, towards those to whom one must always be faithful. In order to live in the community's heart, one thing was especially required - wise husbandry. Today we must better understand the nature of the bond which connects the husbandman with his homestead. We must properly grasp the nature of the labour of husbandry. For we are at risk that we will treat the labour as if it was the work of an industrial entrepreneur. ${ }^{1}$

\footnotetext{
${ }^{1}$ See J. Tischner, Etyka solidarności oraz Homo Sovieticus, pp. 81-82. See also T. Anderson, A Commentary ..., pp. 55-56.
} 
In addition Tischner teaches us that solidarity is not supposed to be against anyone. It is open to all. It is authentic. Solidarity means to carry each other's burden $^{1}$. It matters not so much who is the bad guy or what to do with him. That comes only secondarily - the good Samaritan was not chasing after the culprits, he had something much more important to $\mathrm{do}^{2}$. As Tischner puts it: We want to be a united nation, but not united by fear. We want our most simple, human duty to unite us. ${ }^{3}$ Solidarity is not something which is just a negation to some political movement so that something new could arbitrarily negate it. Tischner admits that we have lost the work ethic of our ancestors, but solidarity, which was its cornerstone, has never left our hearts ${ }^{4}$. One has to accept that people want to have their private land and that there will be no equality of outcome. Yet within that acceptance a man ought to accept that he has his responsibilities towards the neighbour and towards the nation itself $f^{5}$. It is easy to have the desire of becoming rich. The difficulty lies in making that second step - to share what one has earned.

Here Tischner remains an optimist because he fully believes in the free will of a man. One needs to want to be good towards the neighbor, it is that simple $^{6}$. When reading that, we hear an echo of the old, Kantian man mu $\beta$ wollen können. Even if someone already has crossed the line of political corruption and is not viewed by others as an ordinary citizen, the matter remains the same - one needs to want to have a conscience. Tischner reminds us that, [a]s a matter of fact, we are all people in solidarity, because we are all, in the depth of our souls, people of goodwill ${ }^{7}$. Tischner never doubts the freedom of a man, as he writes that: For the good to be exactly that, it must want to be good. It is a similar case with evil: it, too, in order to be evil, must want to be evil. ${ }^{8}$ The belief in freedom is, allegedly, even rooted in the Polish language, since Poles do not say I have freedom, but simply I am free ${ }^{9}$.

It is not the problem that some people are not free in their decisionmaking. The problem is that some people are, it seems, truly evil, i.e. the problem lies in the exceptions. It is hard not to think about the exceptions when faced with totalitarianism, when faced with the question: how could that even happen in the first place? Malice is the name of the exception, for can anyone dare to say that Auschwitz and Kolyma are the products of mere misunderstanding and fear? And yet ... could it be the case that the reason a particular man is evil is exactly that he is not free? We know the danger of

\footnotetext{
${ }^{1}$ J. Tischner, Etyka solidarności oraz Homo Sovieticus, p. 12.

${ }^{2}$ See J. Tischner, Etyka solidarności oraz Homo Sovieticus, pp. 19-20.

${ }^{3}$ J. Tischner, Etyka solidarności oraz Homo Sovieticus, p. 14.

${ }^{4}$ See J. Tischner, Etyka solidarności oraz Homo Sovieticus, p. 69 \& p. 104.

${ }^{5}$ See J. Tischner, Etyka solidarności oraz Homo Sovieticus, pp. 82-86.

${ }^{6}$ See J. Tischner, Etyka solidarności, p. 84.

${ }^{7}$ J. Tischner, Etyka solidarności, p. 13.

${ }^{8}$ J. Tischner, Spór o istnienie człowieka, p. 317.

${ }^{9}$ See J. Tischner, Etyka solidarności, p. 196.
} 
answering yes or even perhaps to that question, namely, since now there is already one exception to the rule (all men are free), why should we stop here, pointing out only the most hideous criminals of history? Should we accept a conception of partial freedom and what would that even mean? Should we, just like Ivan Karamazov, doubt about the existence of the devil?

At least here the answer is a clear no. Tischner acknowledges a case in which the devil has something to say when a man is listening eagerly ${ }^{1}$. That situation, however, is possible only because the individual made himself weak by his own decisions and thoughts, well before the devil could further corrupt him: to become evil, a man has to reach out for evil and must get accustomed to $i t^{2}$. It is not the result that differentiates a man from the devil, but the motivation. Ultimately, a man hates because he feels hurt: evil seems to know that, and from that follows its desire to take possession of man's sufferings. Through the ruling over that suffering comes the desire to rule also over the man himself. ${ }^{3}$ The situation for the one who is being hurt looks like this: something unexpected has happened, but it should never have happened in the first place.

This feeling of being hurt, of losing ground under one's feet, the sensation which triggers other events ${ }^{4}$, is one of the most important issues in Tischner's philosophy. Niezgoda, while analyzing Philosophy of Drama (Tischner's magnum opus), observes what follows:

If philosophy is thinking, then one can ask about the source of thinking - from where thinking arrives? Thinking is freedom, i.e. non-necessity, a man's answer to the suffering and tragedy. To paraphrase Leibniz, one can say that at the heart of thinking lies not the ontological: "Why is there something rather than nothing?", but: "Why do I suffer rather than not?". The establishment of thought within suffering [...] does not mean enslavement. The thought is free. The basic philosophical metaphors - Plato's cave and Descartes' evil demon - are a sign of unusual suffering, namely uncertainty; uncertainty as a peculiar kind of the-possibility-of-being-within-thelie. [...] The goal of thinking is to defeat radical uncertainty. ${ }^{5}$

Tischner agrees with Kant that a man is never a demon, but he does think that a sinner can get closer to this role-model in such brief moments of

\footnotetext{
${ }^{1}$ See J. Tischner, Spór o istnienie czlowieka, p. 38.

${ }^{2}$ I. Marszałek, Józef Tischner i filozoficzne koncepcje zła ..., p. 195.

${ }^{3}$ J. Tischner, Filozofia dramatu, p. 173.

${ }^{4}$ See J. Tischner, Filozofia dramatu, p. 174.

${ }^{5}$ T. Niezgoda, Metafora dramatu ..., ,pp. 78-79.
} 
savagery or madness ${ }^{1}$. As another commentator points out: A man is good in nature as long as he remains in solitude. Evil arises in a moment of crossing to the relations with other people. ${ }^{2}$ Dialogue is the only source of truth that matters ${ }^{3}$, and yet, exactly because of that, this is also the source of deception ${ }^{4}$. Tischner defends his thought that, when it comes to the topic of people, the discovery of truth often includes the discovery of evil, namely in a situation where there is a sense of something going terribly wrong. That feeling comes from the realization of the proper connection between people - the connection which has been broken ${ }^{5}$. One example of that is the following.

\section{The example of living close to the spectre - Andrey Srubov}

The movie The Chekist by Aleksandr Rogozhkin ${ }^{6}$ portrays a Bolshevik, a prime figure of that which is evil for Tischner. The protagonist, Andrey Srubov, the leader of a local Cheka unit, is a philosopher who continues to defend the revolution. In the culminating scene of the movie, he invites his subordinate to dinner, where Srubov's mother openly blames him for doing that. He has just invited the murderer of his father. The subordinate makes apologies, but Srubov calmly suggests that this was nothing and that they should start talking about more serious topics. All seems peaceful, but just minutes before that scene his wife left him for good without a word of explanation, and before that the doctor of the aforementioned wife, a friend of the family who was once present around the same table, was being shot before his death he revealed that he knows that Srubov's wife is still a virgin. His last words were simple: You are sick, Srubov. That scene is related to Tischner's philosophy:

The encounter with another man is in the deepest sense of this word - an event. In it, the experience of another man and the experience of oneself that is being mediated by it reaches the summit of noticeability [naoczność]. Its summit is also reached by the power of persuasion that is being present in the experience. It is as if from the moment of encounter everything in man's life begins anew. The encounter constitutes a departure from the given space of being together with the other. The encountered other does not fit in any of the basic areas of being together: he

${ }^{1}$ See T. Niezgoda, Metafora dramatu ..., p. 38. See also I. Marszałek, Józef Tischner i filozoficzne koncepcje zła ..., pp. 84-93.

${ }^{2}$ I. Marszałek, Józef Tischner i filozoficzne koncepcje zła ... , p. 93.

${ }^{3}$ See J. Tischner, Filozofia dramatu, p. 215.

${ }^{4}$ See J. Tischner, Filozofia dramatu, pp. 188-189.

${ }^{5}$ See J. Tischner, Spór o istnienie czlowieka, p. 145, pp. 149-150 \& p. 233.

${ }^{6}$ The movie is based on Vladimir Zazubrin's short novel, The Splinter: A Story About Her and Her (1923). It was only available to the public in 1989 , the movie appeared three years later. The author was executed in 1937 by firing squad, just like the protagonist in his novel. Rogozkhin decided to make the death symbolical in the movie - a spiritual death, much in the tone of Tischner's philosophy. 
does not appear as the fellow worker who is being introduced by the wieldy [narzędziowe] structures of the surrounding world, nor as the adversary who has to be fought with, nor as my lord, nor as my servant. The one I encounter is different. [...] My whole previous way of being is becoming problematic. ${ }^{1}$

Indeed, the doctor was quickly killed, but the doctor never stops saying the words because the dialogue continues in Srubov's head. From Srubov's reaction that follows the event, we are convinced that the doctor in his memory is harsher than the doctor who was standing before him in the flesh. It is as if the doctor inside his head is telling him: [t]his is not about the revolution, Andrey. You are an impotent man, for that reason we are all being murdered. Even your own father was killed for a similar stupid reason, yet you explain to your mother and your father's murderer that it was nothing. Little by little the story plays inside Srubov's head, moving backward, revealing more and more details, including how his mother, his wife, and the doctor all looked at him with silence when the four of them were sitting around the dinner table. It is worth noting that, according to Tischner, [t] he immediate source of shame is the gaze of the other. It throws me into a state of accusation. [...] At that moment I discover that the other is. ${ }^{2}$

Srubov cannot escape the dialogue. Yet since he had already gone all the way down in the path of evil, only madness awaited him. Violence grants freedom no more. It becomes that which is expected, it becomes the feeling of necessity. From now on violence is supposed to be the reward and gratitude is for the one who can take part in it. The road of the wicked has become the end-goal ${ }^{3}$. This is not something that Srubov was ready for. He discovers that despite his ruthlessness, he is not a mindless machine. He was all too ready to sacrifice the lives of others, but not his sense of dignity. Srubov needs to fight for something that he believes to be righteous, something that he can ponder about, something which will elevate him above all the rest ${ }^{4}$. No matter what the reason was that he joined the Cheka, he cannot fully describe it anymore. He becomes distant from the Srubov who made that decision, yet he cannot turn back time, and he is too stubborn to admit his guilt. What he finds out is that the fact that he is in the centre of things is only an accident. He found himself to be here not because of being better than others, but because of a disturbing shortfall, his impotency ${ }^{5}$. If we accept that sin originates from selfishness, then we can understand that this revelation is too much for Srubov. From the nature of evil flows the hidden desire for self-destruction ${ }^{6}$.

\footnotetext{
${ }^{1}$ J. Tischner, Fenomenologia spotkania, p. 75.

2 J. Tischner, Filozofia dramatu, p. 69.

${ }^{3}$ See J. Tischner, Etyka solidarności, p. 72.

${ }^{4}$ See P. Marcus, In Search of the Spirituality ..., pp. 94-95.

${ }^{5}$ See T. Anderson, $A$ Commentary ..., p. 38.

${ }^{6}$ See J. Tischner, Fenomenologia spotkania, p. 78.
} 
When just before Srubov's suicide attempt his companion in crime, smiling from ear to ear, told him: just imagine, the two of us are that kind of new people who were created specifically to eliminate the parasites, Srubov could no longer let him speak, breaking that lie with a sharp protest: nonsense. Nonsense ... . However, he still claims that he does not know why exactly this is nonsense. Tischner gives us a warning in the spirit of that confession:

A danger greater than death is the state of damnation. It is when the ontological consciousness of evil occurs: I am evil and as such I do not have the right to be, and yet I am. The pain of this contradiction - a contradiction which has become me - is the actuality of the damned. [...] The damned one found himself under the power of evil. He wanted it himself. If he had not, it would not have access to him. On the other hand, there is still some freedom in him that cannot want and remains not being able. [...] In the nature of damnation lies the struggle towards universalization of the state of damnation. Hence, the need for help from the outside. But who is able to help? Only God, who justifies. However, can there be a justification without a reason? ${ }^{1}$

It is as if hell was truly not a place, but a situation where it cannot get any better or worse, and no one has the power to change anything ${ }^{2}$. When nothing matters anymore, then the loss of meaning hurts like atrophy [obumieranie] ${ }^{3}$. After the incident with the doctor, Srubov killed a woman who was asking kindly to be left alone, just when no other Chekist was willing to shoot her. It changed nothing. After the incident with the doctor, Srubov spared the lives of the rebellious soldiers of the Red Army when every Chekist was ready to shoot them. It changed nothing. After the incident with the doctor he looked through the doctor's glasses - the glasses that were taken away from the doctor before his execution - as if Srubov was hoping to find something new from his perspective, but he could see nothing ${ }^{4}$. It is just like Tischner himself said: Revolution is the historical blossom of freedom, as well as the grave. ${ }^{5}$ True, we, the neutral observers, can say with confidence that Srubov is free. After all, he can spare some lives, he can try to escape by train, refuse to follow orders, he can sacrifice himself by consequently opposing the system, be it openly or secretly. The situation of his comrades is exactly the same. Yet Srubov does not really want to change anything, he wants everything to remain the same. Even his final transformation boils down to him willing

\footnotetext{
${ }^{1}$ J. Tischner, Spór o istnienie człowieka, pp. 190-191.

${ }^{2}$ See J. Tischner, Spór o istnienie człowieka, p. 56.

${ }^{3}$ J. Tischner, Spór o istnienie człowieka, p. 205.

${ }^{4}$ See G. Marcel, Homo Viator, p. 148. Z. Dymarski, Dwugłos o ztu ... , p. 81, points out that one of the ways of looking at evil in Tischner's philosophy is from the point of view of misunderstanding.

${ }^{5}$ J. Tischner, Spowiedź rewolucjonisty ..., p. 35.
} 
nothing anymore, relying only on his blissful memory of the past ${ }^{1}$, a bliss that became at least sometimes possible because there were no physical reminders anymore, no dead bodies or any other fruits of the revolution ${ }^{2}$. But even his bliss contains the joyful memory of the time spent together with his companions in crime, away from the gate of the execution chamber, in the wilderness. It is not his father whom he associates with bliss. It is those who murdered him, that part of the firing squad which he considers his friends and companions. He seems to believe that the father was never there and that they had never murdered anybody. The limits of his coherent denial are that which drove him crazy $^{3}$. And this is no coincidence when Tischner calls that an ontological consciousness of evil, not psychological or existential ${ }^{4}$.

The child of the revolution thinks this is so, this is so, because in his mind there could not be anything else, anything less or more. Srubov is evil because his drama is not about the blame, but about the will to remain, the will to be ${ }^{5}$. Outside the ideology Srubov is left with nothing. That is why it was so devastating when the doctor suggested that it was not at all about the revolution. There is no feeling of freedom within the movement, be it from the perspective of those who are being killed or those who kill. The so-called historical necessity seems to move by itself. Even though that is just a lie, it is a powerful one, the one in which the criminals themselves believe. The lie is powerful because it is hard to pin-point the watchful author of that lie, to prove that someone is a hypocrite and not just a madman ${ }^{6}$. However, that still counts as a lie and that still counts as being responsible. One has fallen into the trap of a lie not because he had to, but because he was not careful with his thoughts and actions ${ }^{7}$. What was decisive in Srubov's drama of evil was a question that was asked by the doctor, the question that emerged from the silence within the dinner table. That question made the doctor something more for Srubov than just one of his many victims, despite him trying to run away from the question when it was asked and from the memory when it was all over. The question, as a sign, a promise of redemption, gave hope, since, in normal circumstances, the thing with the good is that it only needs to be noticed so that a man will want to be good himself ${ }^{8}$. The question was painful, because it was not a hidden accusation, nor was it a defense, nor was it something that came as an initiative opposing the will of Srubov. The question was a sign of the Good that does not need evil for its existence. The following fragment from The Philosophy of Drama lets us understand that situation:

${ }^{1}$ See G. Marcel, The Mystery of Being, p. 69.

${ }^{2}$ J. Tischner, Etyka solidarności, p. 74.

${ }^{3}$ See G. Marcel, Homo Viator, p. 96 \& G. Marcel, The Mystery of Being, p. 68.

${ }^{4}$ See J. Tischner, Spór o istnienie czlowieka, p. 190.

${ }^{5}$ See J. Tischner, Spowiedź rewolucjonisty ..., p. 203.

${ }^{6}$ See J. Tischner, Filozofia dramatu, pp. 202-206.

${ }^{7}$ See J. Tischner, Spowiedź rewolucjonisty ..., pp. 222-223. See also J. Tischner, Filozofia dramatu, p. 8, W. Glinkowski, Problem sceny ..., pp. 72-75 \& A. Wesołowska, Fenomenologia i agatologia, pp. 86-87.

${ }^{8} \mathrm{~J}$. Tischner, Wiara ze stuchania ..., p. 112. 
Everywhere around me and close to me there are people, especially those who are the participants of the same drama, in which I, too, participate. Contrary to the widespread opinion, I do not see them, hear them, touch them or notice them at all. It is so because that which I do notice is only the outerness and not the man as a man, the other as the other. The other man as a man can show up only then, whenwithout the exclusion of all the outerness - he will stand before me as the participant of my drama. [...] The consciousness of the fact that the other is present fulfils itself as the consciousness of a claim - a claim which obligates. So, your question reaches my ears. There is a moment of silence, the mutual present time. You await an answer. An answer must be given. This must is important. Because of it and within it you are present by my side. ${ }^{1}$

The question that Srubov hears is: How do you feel, Andrey Pavlovich? And the quick answer is: I feel wonderful. Wonderful. Wonderful. From that one lie came the others ${ }^{2}$. The doctor had his role to play, but it was a very difficult one. The doctor visited Srubov because Srubov's mother thought he is not himself anymore (perhaps, then, this madness is only temporary?). The doctor appeared as the old friend of Srubov's dead father. It was as if he was about to speak in the name of the absent father. Srubov gave the doctor no chance of fulfilling that role, leaving at once. The sign of evil is clear with Srubov: he is the one who cannot, by his own, forgive ${ }^{3}$, which is a disastrous situation when one is blaming the world - perhaps God himself - for his suffering. The father was repelled from Srubov's consciousness (judging by the end of the movie), and so the one who speaks with his voice must also be repelled ${ }^{4}$. We can describe the doctor's situation with Tischner's words: While seeing the other during the encounter, I do not yet know what I should do, and what I should not do, I do not know if I should do anything at all, if there even is something to be done here. I know one thing: it should not be like that. ${ }^{5}$

Srubov could not tell himself that lie anymore. Instead of facing the truth head-on he was rather willing to run away once again. At that point, no one could even oppose him or suggest something. The dumb Chekist who killed his father - the closest that he has to having a friend - could not understand the weight of his words, he could only make a suggestion by giving him more alcohol. The words could not even be as clear as Srubov's thoughts, the facade of composure has been broken. It is as if Srubov is telling himself:

\footnotetext{
${ }^{1}$ J. Tischner, Filozofia dramatu, p. 9.

${ }^{2}$ See A. Bobko, Myślenie wobec zła ..., pp. 148-150.

${ }^{3}$ See J. Tischner, Na drogach krzyżowych historii ... , p. 29.

${ }^{4}$ See G. Marcel, Homo Viator, pp. 76-77 \& p. 101.

${ }^{5}$ J. Tischner, Fenomenologia spotkania, p. 82.
} 
I cannot rest! I must continue. The revolution is filthy, but it is we who must cleanse it from maggots. We must protect it and push the revolution to its final, peaceful chapter that reminds us of the first one - the clean, white shirt of Karl Marx. The blood is that which the revolution needs right now, not theory. The I who must kill and the I who thinks are one and the same, and to think is futile, since either way I must kill. Justice or not, this is my duty, these are my orders, these are my phone calls. Besides, I am too tired right now to think ... it makes me even more tired ... and I have no right to be tired. I must be ready.

The thinking circles around some values, but these are only there to hide something, they are the rationalization of the $\sin ^{1}$. There is no good or justice or hope as their foundation. Srubov is deeply mistaken, he fools himself. It is not about a theory or the criticism of some theory, not about the maggots or the peaceful chapter, or about a solution to a difficult puzzle, or duty or orders, or phone calls, or physical exhaustion of his body. These were just some additional lies and excuses. It was all about a decision that he was unwilling to take. Srubov was willingly saying no to his inner voice of good. According to Tischner:

That which is agathological throws a man away from the present cycle of day and night, throws him into the limit situation, in which freedom accepts or rejects itself, reason wants or wants not to be a reason, conscience renounces itself or acknowledges itself. ${ }^{2}$

The decision that would be the right one was to try to stop that which was happening. The decision to begin as a new man, to really change his behavior, was always a possibility ${ }^{3}$. Yet he would rather destroy himself than begin once more, and though he prays to God during his suicide attempt (just like his victims were praying at the beginning of the movie), this is not enough, and the ending scene, just before and during the credits - i.e. the image he sees on the other side - negates the significance of any major transition ${ }^{4}$. The story is about the one who suffers alone because he does not want to see the suffering of others, the one who allowed the anti-gravitation of evil to make him a monad ${ }^{5}$. Together with Tischner we can add:

Evil causes the total helplessness of a man in the face of another man. Nothing can be done here anymore.

\footnotetext{
${ }^{1}$ See Z. Dymarski, Dwugłos o ztu ..., p. 29.

${ }^{2}$ J. Tischner, Fenomenologia spotkania, p. 82. See J. O'Malley, The Fellowship of Being ... .

${ }^{3}$ See J. Tischner, Filozofia dramatu, p. 307.

${ }^{4}$ See G. Marcel, The Mystery of Being, p. 63.

${ }^{5}$ See J. Tischner, Spór o istnienie czlowieka, p. 224.
} 
We are at different levels. There you have it, a windowless monad. We went beyond the circle of the available participation. One can grasp the hair color of the monad, its voice, its name, one can even patch its wounds, but it is impossible to understand it, to communicate with it, invite for participation. My thoughts are not your thoughts and your thoughts are not my thoughts.

The dialogue continues when the other is no longer there, and all the pain becomes unbearable. That is the prime source of evil, which goes from one person to the other, like a domino. Tischner adds: Because the fundamental trait of evil is that, once implemented, it does not disappear, but, in some way, it continues. The continuation of the past evil is closely connected with the continuation of some kind of pain. ${ }^{2}$ Evil does not stop just because there is no room anymore for more violence within the individual. The violence has already been done, and it is being carried away by others. Tischner reminds us that:

In the world of Kolyma, the participation in power simply became a man's raison d'être. I rule, therefore I am. I am to such an extent as I rule. Outside the structure of power, I am nobody.[...] By killing the other, I confirm my right to existence.

We see an obvious example of this. When Srubov is being taken away to the asylum, another Chekist looks down on him, as if he was always ready to do the job better - as if Srubov's thoughts are returning and materializing more consistently inside a new man: this is nothing. Nothing serious has happened. When he already is in the asylum, yet another Chekist looks at him closely, smoking a cigar, as if stating that Srubov's mistake was that he thought too much, that all he needed to do is to observe and take action. Evil shows itself from every angle possible. Nothing is being stopped when Srubov is being taken away by other Chekists. They do all they can to maintain order, continuing the mass murder as usual. It truly seems like evil is something that is between people ${ }^{4}$, something that Tischner calls a spectre. That spectre can create such an atmosphere of madness that even he who dies by his sword will never acknowledge the reality, will not meet the other ${ }^{5}$, and if he has no choice but to acknowledge it, then he will never acknowledge his mistakes:

Standing in front of a guillotine, the revolutionist turns his last gaze back. How did this come to be that he dies in a way that he envisioned for the enemy of the people? What happened that people are demand-

\footnotetext{
${ }^{1}$ J. Tischner, Spór o istnienie czlowieka, p. 224

2 J. Tischner, Filozofia dramatu, p. 174.

${ }^{3}$ J. Tischner, Filozofia dramatu, p. 55.

${ }^{4}$ See J. Tischner, Filozofia dramatu, p. 175.

${ }^{5}$ See J. Tischner, Filozofia dramatu, p. 160.
} 
ing his death? The revolutionist does not understand.

He strikes the pose of a hero. ${ }^{1}$

The problem that we face is the consciousness that which Zazubrin was writing about was only the beginning of a process. Things were about to get worse (vide Solzhenitsyn) and it has a lasting imprint on our minds.

\section{The problem}

The coherent denial of an evil man is possible as long as the evil system will not shout that he will die next. But just because the denial cannot be coherent does not mean that it is not possible at all, up to the very end. Some truly do not regret their actions, and not because it is impossible for them though surely, when they are close to a limit situation, they think that way, they believe that this is the case ${ }^{2}$. There is always a room for another excuse. As Dymarski puts it: [t]he tragedy consists not in only the triumph of evil, but even the sole possibility that evil can defeat good. [...] But a man would want to be a man - he does not want to perish. [...] [t] hat is one of the basic assumptions of his [i.e. Tischner's] philosophy. ${ }^{3}$

Now if someone asks us if we, the others, can overcome that situation, what should we tell him? It would seem that one needs to overcome the absence - the concealment - of someone else's conscience. That is how totalitarianism is born - from within. There is some hope, since the unwillingness to change depends on a perpetual lie. The perpetual lie can, indeed, be stopped, provided that the truth will always be with us. For every lie, we shall tell the truth twice ${ }^{4}$. There are two problems with that strategy: 1) we would have to assume that one will not be evil if he is not ignorant anymore, 2) we would also have to assume that the amount of lies is small enough to not overwhelm us, that it will not, so to say, go under the radar of the decent people.

Thankfully, there is a clear answer to the second point, namely: as long as there is a system which goes against our sense of dignity - because it lies to us that in order to keep our dignity we must stomp on the dignity of others - we have our hope (and the right to spread that hope) that beyond that system awaits a new epoch of people's interaction with each other ${ }^{5}$. Or, to put it in simple terms: we notice the light, however thin it might be right now, thanks to the shadow. That is the road that unites our pilgrimage on Earth with the afterlife ${ }^{6}$. Tischner says: A man may not search for salvation (the good) beyond the truth, whereas it is allowed and required to ask if beauty and good that are being promised to us by others are truly the Beauty and truly the

\footnotetext{
${ }^{1}$ J. Tischner, Spowiedź rewolucjonisty ..., p. 291.

${ }^{2}$ See J. Tischner, Spór o istnienie czlowieka, p. 345.

${ }^{3}$ Z. Dymarski, Dwuglos o złu ..., p. 56.

${ }^{4}$ See J. Tischner, Spór o istnienie czlowieka, p. 309 \& pp. 311-312.

${ }^{5}$ See G. Marcel, Homo Viator, p. 7, pp. 10-11, p. 16, p. 18, pp. 22-26, p. 32, pp. 48-51, p. 53, p. 58, p. 61, p. 63, p. 67, p. 91, pp. $94-96$ \& p. 126 \& G. Marcel, The Mystery of Being, p. 47.

${ }^{6}$ See J. Tischner, Etyka Solidarności, p. 88, p. 104, p. 113 \& pp. 115-116.
} 
Good. One does not enter heaven any other way than through the gates of truth. ${ }^{1}$

The first problem remains, and it must have come to Tischner's attention before he wrote his last book. Is it really always the case that the source of evil is ignorance, and, thus, that the remedy to evil is wisdom? We need to be concerned first and foremost with values, not with pragmatics. This applies also when bad things happen - when the values are the opposites of that which Christ is teaching, when the values manifest themselves during the bloody (i.e. unauthentic $^{2}$ ) revolutions ${ }^{3}$. Understanding the motives of the wrongdoers is essential, but not so much the methods; only the former justifies the need to understand the latter. But why is that important? It is important because evil uses not only threads; it also entices us with what we desire, so it seems that evil has an answer to our every movement ${ }^{4}$. By keeping our eyes on the values we not only are striving to become morally good, but we also can understand evil. It matters not what evil might be. What matters is the simple question: what does evil want from us ? By perceiving evil as if it was a person Tischner already gives us the sense that it is something which strikes us suddenly and which is hard to grasp, yet something from which we cannot really run away ${ }^{6}$, just like Srubov's victims could not run away from the state, they could not opt-out from the system. Sometimes it seems that evil does not even know what it does want, that it is cunning as far as the method goes, but stupid because of the lack of a clear goal. It only knows what the other wants, and hence it casts an illusion in other to destroy ${ }^{7}$. Sometimes it wants everything, which should be read like this: where there is no answer to the meaning of life, the strife for power becomes the default answer; when people who think that way are becoming a legion through the examples of individuals like Srubov, we witness that which rivals the most vivid imagination ${ }^{9}$. Two things originate from this. On the one hand, evil, just like a plague, moves from one person to the other, it becomes normalized (as a rule: under the guise of a lesser evil, and it is a guise because evil is nothing static it accelerates ${ }^{10}$ ). On the other hand, one by one it removes the options from those who wish to oppose it since a good man usually makes his actions open to the public, while the evil one usually shows all of his cards only when he no

\footnotetext{
${ }^{1} \mathrm{~J}$. Tischner, Myślenie wedlug wartości, p. 363.

${ }^{2}$ See J. Tischner, Etyka Solidarności, p. 22 \& p. 74.

${ }^{3}$ See K. Wieczorek, The Ethics of Solidarity ..., p. 72.

${ }^{4}$ See J. Tischner, Filozofia dramatu, pp. 171-173.

${ }^{5}$ See J. Tischner, Filozofia dramatu, p. 261

${ }^{6}$ See I. Marszałek, Józef Tischner i filozoficzne koncepcje zła ..., p. 167.

${ }^{7}$ See J. Tischner, Filozofia dramatu, p. 174

${ }^{8}$ See J. Tischner, Spowiedź rewolucjonisty ..., p. 203.

${ }^{9}$ See I. Marszałek, Józef Tischner i filozoficzne koncepcje zła ..., p. 26.

${ }^{10}$ See J. Tischner, Spowiedź rewolucjonisty ..., p. 223. See also Z. Dymarski, Dwugłos o złu ..., p. 535.
} 
longer fears any opposition ${ }^{1}$. Of course, human beings are fragile, so limiting their options is not a difficult task, as shown by Tischner:

He who once went through the hell of unsatisfied needs always has a deep fear that hell will return. Once I knew a man who during the war fought in the underground movement for five years. When the war ended, he could not get rid of one particular habit: whenever he was about to sit in a room, he always had an eye on the door. Just as if the underground fear of an enemy who appears unexpectedly had never died within him, so, too, the spectre of starvation never dies for those who survived Kolyma. [...] Fear of starvation becomes then, at the same time, a fear of the other. [...] Who is the other? He is my sensation of hunger. He distributes my food. The other takes away my bread. The other is eating what I could eat. The harsh imperative of hunger is directed against others. Is that fear of people the fear of death? Undoubtedly death is nearby. But also far away. Death does not hurt, but hunger does. And it is not only about stomach cramps, but it also includes humiliation. The hunger primarily humiliates. ${ }^{2}$

In that context the sentence [t]he first experienced freedom is not my freedom, but the freedom of the other $r^{3}$ is granted a wicked twist. A man who is free does not always want the freedom of others. He often wants to take it away ${ }^{4}$.

Tischner wrote that [b]etween the stance of Abel and that of Cain there is no third possibility ${ }^{5}$. The pacifist's conclusion of a feeling of responsibility for a brother, a feeling that is already ahead of any moral theory ${ }^{6}$, namely the brother who even goes as far as fulfilling the need to murder me, is simply the correct approach, even if the scenario itself is far from normal. Tischner's Abel has this to say to Cain:

Yet above all else try to understand this one thing: since God has chosen me, your brother, He can also choose you. Don't you see that in the fact of me being chosen lies the possibility of you being chosen? It is not the case that God is choosing some and rejecting others. God only chooses. By choosing me, He has

\footnotetext{
${ }^{1}$ See J. Tischner, Filozofia dramatu, p. 174.

2 J. Tischner, Spór o istnienie czlowieka, pp. 89-90.

${ }^{3}$ J. Tischner, Filozofia dramatu, p. 72.

${ }^{4}$ See J. Tischner, Filozofia dramatu, pp. 172-173.

${ }^{5}$ J. Tischner, Filozofia dramatu, p. 48.

${ }^{6}$ See J. Tischner, Etyka Solidarności, p. 17 \& J. Tischner, Krótki przewodnik ..., p. 20.
} 
chosen you, provided that you will be my brother. Be my brother. Don't hit me ....'

Abel allowed himself to be killed, led by the feeling of brotherhood, a feeling which neither asks nor answers questions for oneself, reserving everything for the other; perhaps even purer than the feeling of Abraham in front of his beloved son, since this time one needs to just allow the knife to be put on his neck. We should remember that Tischner says: The more Cain is evil, the more holy must be Abel. This is the only way that Cain may understand that in the choosing of one resides the pledge for choosing others. ${ }^{2}$ This is a mentality that surpasses the maxim of God gives and God takes away. But Cain, it seems, did not understand. T. Niezgoda puts it this way: The face ${ }^{[3]}$ says: do not kill, and yet as if at the same time, by that very speech, invites violence. ${ }^{4}$ No matter what holiness stands in front of a man, there is always the possibility that he will answer: you most certainly will not tell me what to do! After all, one can stand in front of the epiphany of the Face only when he opens himself to Infinity through the desire ${ }^{5}$. This kind of reflection will push Tischner to write these words: only death which results from a sacrifice gains a deeper meaning. I die instead of you ... I die for you ... From my death comes your life. ${ }^{6}$ Christ died also for those who wished for his death, those who wanted to have a spectacle ${ }^{7}$. It is Christ who will need to remind us once more to turn the other cheek.

Never did Tischner suggest that Cain made his sin because he was unfree. On the contrary, it is exactly because he is free that Abel had his hope to the very end: [d]on't hit me ... Be my brother ${ }^{8}$. There is no doubt about freedom here. The problem is different:

But is it really the case that Augustine knew all the names of despair? Was he not writing his Confessions in the mood of the deepest gratitude? We are in a different situation: we know despair, and we know the power of retaliation that is rooted in it. [...] Could it be that for that reason this beautiful principle that a man always does evil because he has an illusion of good - must be criticized? Perhaps there are exceptions? Perhaps it should be said: it is so until the

\footnotetext{
${ }^{1}$ J. Tischner, Krótki przewodnik ..., p. 148.

2 J. Tischner, Krótki przewodnik ..., p. 148.

${ }^{3}$ See J. Tischner, Fenomenologia spotkania, p. 74: The face is not an 'essence', it is rather a 'process of expressing the essence' ['istoczenie'], a 'place' in which a man's truth appears. A face is a bustle [ruchliwośc centred around some truth. In order to not distort that bustle in the description, there is often the need to make use of the language of metaphor, symbol; to show more than one is stating explicitly.

${ }^{4}$ T. Niezgoda, Metafora dramatu ..., pp. 91-92.

${ }^{5}$ T. Niezgoda, Metafora dramatu ..., p. 92.

${ }^{6}$ J. Tischner, Spór o istnienie człowieka, p. 121.

${ }^{7}$ J. Tischner, Fenomenologia spotkania, p. 84

${ }^{8}$ See K. Wieczorek, The Ethics of Solidarity ..., , p. 83.
} 
principle of retaliation appears. At that point, man is ready to do evil because it is evil. ${ }^{1}$

Tischner leaves us with an image of the atrocities of the $20^{\text {th }}$ century: Auschwitz and Kolyma. Standing in front of those places, is it really the problem if their creators are free or not? It is safe to assume that this is not the question that begs to be asked. It does not change much. What is frightening is that free people, people of goodwill, could do nothing to stop this from happening. What is frightening is the contrast between the powerful and the powerless, the absurdity of rebellion within Auschwitz and Kolyma ... as well as the silent reaction of those living outside. Tischner tells us that:

In the end, it is man who has built Auschwitz and Kolyma. When he was building it, he had some kind of satisfaction. As he has now finished building it, he wants to clean his hands. He who has built Auschwitz and Kolyma would want to prove that he had nothing to do with anything, that everything happened by itself, behind his back. [...] That which hell could not achieve is taken up by man himself: he wants to prove that what he did, he did not, because he was never there. $^{2}$

The perpetual lie tells us something like this: there was no freedom, there was no image of God because there was no God in the first place. We are just animals; we react the way we do out of necessity. Many people would never believe that lie, and they all had to face the Chekists. So the lie goes on: what we are creating right now is a boogeyman who is supposed to be this "evil Communist"; even if he had done some cruel (but necessary!) things, his heart was not there. Those who tell that lie only want to talk about a man who did this or that (as in: if he did not, if that was not his hand, then there is no $i s s u e^{3}$ ). We should see it differently, we should want to talk about a man responsible for the other, just like Ivan Karamazov was feeling responsible for the death of his father, even though he never killed him. Srubov did not kill his father as well, but the difference is that we witness that he was ready to do so, and that is enough.

Perhaps the last interview with Pol Pot is the best example of what Tischner is saying about the one who built Auschwitz and Kolyma. We see a charming, quiet old man who says: look at me now. Do you think ... Am I a violent person? No. A man who is concerned with proper thinking through values will simply look at the results, will keep those results in memory. By doing so, we recognize evil immediately ${ }^{4}$. The exceptions to a rule of minimal decency are not tiny, but monstrous, as they are the stages of the $20^{\text {th }}$ century. Within those stages, one must play his role in the drama of life. A lot could be

\footnotetext{
${ }^{1}$ J. Tischner, Spór o istnienie człowieka, p. 350.

${ }^{2}$ J. Tischner, Spór o istnienie człowieka, pp. 56-57.

${ }^{3}$ See A. Bobko, Myślenie wobec zła ..., pp. 165-166.

${ }^{4}$ See J. Tischner, Filozofia dramatu, p. 172.
} 
said right now about the difference between the world of Auschwitz and the world of Kolyma, but since Tischner does not develop that issue explicitly he only gives us subtle hints that the latter was more tragic - let us leave this issue as well.

The only thing that is important here to remember is that those who crossed the line of spreading evil for its own sake do not step aside just because their lives are at risk. The need for remaining in power becomes something unconditional, and thus it is the prime shape of evil ${ }^{1}$. Tischner, however, throws cold water on our belief that it is only about those high in power. The system needs its knights (vide Srubov) to start ticking. Tischner ponders about the thought process of a revolutionist in the following way:

It takes courage to do evil, so that from evil good shall spring. One needs the courage to denounce his parents if it is the case that from that courage will emerge a society free from exploitation. Only the Communists "have the courage" to cleanse the society from "the seed of evil", which has already grown from the heart of industrial society. The courage of the revolutionist consists in loving your neighbour more than yourself. Communism needs such children to build a better world, children that are ready to offer their fathers on the sacrificial altar. $^{2}$

It is unclear how ironic this message is supposed to be: it takes courage ... Perhaps there is no immediate irony here. What Tischner is describing is another faith, a faith in which no angel will stop Abraham's hand. Communism is mimicking religion ${ }^{3}$.

Tischner has also shown us the same truth from a different perspective. Here you have not Abel, but Socrates, who does not move and is unwilling to escape from the prison because he wants to defend the truth to the bitter end. Socrates would rather lose than respond with deception. He is the one who uses that which Tischner calls descriptive reason, which focuses not on the many thoughts and opinions of others, but on the objective reality, with the assumption that there is a clear, objective reality independent of those many thoughts and opinions ${ }^{4}$. Tischner adds: But where is that objective reality? [...] That which is being called objective reality is only a temporary state of affairs, determined by the current history of knowledge and self-knowledge of $a m a n^{5}$ - at least that is what the opposition, like Socrates's opponents, would like us to think. We are talking about people like Rodion Romanovich Raskolnikov. This is how Tischner describes the character and his situation:

\footnotetext{
${ }^{1}$ See J. Tischner, Filozofia dramatu, pp. 192-193.

2 J. Tischner, Spór o istnienie człowieka, pp. 53-54. See also G. Marcel, Homo Viator, p. 209.

${ }^{3}$ See J. Tischner, Rekolekcje paryskie, pp. 242-243 \& J. Tischner, Spór o istnienie człowieka, p. 197.

${ }^{4}$ See J. Tischner, Filozofia dramatu, p. 142.

${ }^{5}$ J. Tischner, Filozofia dramatu, p. 159
} 
Who has won in the dialogue of interrogation? The winner is Raskolnikov. His victory consists not only in that he did not allow himself to be pulled into a trap, but, above all, that he could convince himself that by killing he did not commit a crime; instead, he has contributed to the progress and happiness of mankind. The means of victory boil down to the alteration of the notion of truth. Truth is not anymore the conformity of cognition with reality which applies to that cognition, but the conformity of reality that is being created by a man with the already undertaken ideal project of its rebuilding. Raskolnikov cannot explain that all to the committing magistrate, since the committing magistrate is unable to understand anything, having the already prepared thoughtpatterns to trap Raskolnikov's beliefs. The committing magistrate is part of the world that ought to disappear. Raskolnikov's victory consists not only in the life that was being saved. The dispute that we are witnessing is a dispute for power. To gain power, one needs to present himself as the righteous among the unrighteous. The victory comprises self-justification. To justify oneself means to prove that one is not a liar. Raskolnikov, thanks to taking into account the political reason, proves that he did not murder. Therefore, he is not a liar. His action was really an act of heroism. And even though the committing magistrate has a different opinion about that, it does not really matter that much. As follows, Raskolnikov is worthy of having power. Thanks to the ability of anticipation and heroism, he can be the leader who leads society to a better future. Raskolnikov has not renounced the truth. He merely changed its meaning. He is fully conscious of the significant role that truth plays in the lives of people and nations. He does not intend to rule any other way than by truth. [...] Dostoyevsky shows us a defeated character. But we do not believe him, Raskolnikov has won, and he has the power. ${ }^{1}$

Srubov was evil, but he was not the centre of human tragedy, he was merely at the centre. He finally admits that with a kind of sorrow that before would have been something hard for him to comprehend. The tragedy occurs when evil is triumphant ${ }^{2}$, and this is exactly what Tischner recognizes in Raskol-

${ }^{1}$ J. Tischner, Filozofia dramatu, pp. 165-166.

${ }^{2}$ See J. Tischner, Fenomenologia spotkania, p. 78. 
nikov. The evil which presented itself in Srubov was oriented through the fascination with violence and the sense of duty. Srubov could only perish, perish by his own hands or by the hands of another criminal. Raskolnikov's evil is triumphant because the evil man can convince others to the moral superiority of his standpoint, which is exactly what happened at the end of the $19^{\text {th }}$ century. Evil is being triumphant when it reaches the balance of using threats and promises accordingly to the need for every given situation ${ }^{\text {. }}$ Srubov is willing to kill simply because it feels good to have the inner strength to do so. It is the pleasure of answering: no, I do not regret. Raskolnikov, given the right circumstances, is more dangerous, in the sense of an evil that is being fertile, the evil that gives promises ${ }^{2}$. He is willing to promise the death of the other for the sole benefit of mankind, and he convinced himself that this is indeed the case, having enough willpower to give away money when he has very little. Srubov has only convinced himself to be unbreakable. Raskolnikov has convinced himself to be good. Raskolnikov is the one who would sit and argue with the doctor, trying to convince both of them that his understanding of things moves far beyond that which is seen on the surface. Raskolnikov would explain patiently to his wife everything that is horrible, and the wife would listen eagerly. He would be open, ready to tell his story to everyone ready for it. It is only the triumph of people like Raskolnikov which makes the possibility of lack of opposition for people like Srubov. The wish about the part of the world which ought to disappear had become reality. When Tischner writes in the previous quotation that Raskolnikov is worthy of having the power, he means that. He means that in the sense that some sincerely believe this, and they know how to argue in favor of that viewpoint, how to maintain their ideology - and from there their envisioned reality. To be a man of truth, one has to be honest with himself ${ }^{3}$. The mystery concerns the fact that some people are indeed being honest, and we still are afraid of them; the political truth results from that mystery of evil ${ }^{4}$.

Tischner gives us now a clear image of what happens when the tables turn. And so, once more, over there you have the so-called political reason, which strives to create the world from scratch ${ }^{5}$, the reason which, when it has the upper hand over its enemies - which Raskolnikov had not - appears as the Grand Inquisitor, the great Enemy of God . It was a story read by Ivan Karamazov to his brother Alyosha during Alyosha's inner crisis. Ivan, who will later leave his father, knowing well that the father will be murdered, now just wants to influence the pure-hearted Alyosha by using a story at the right moment $^{7}$. The Inquisitor, being like a spirit tempting two people during their

\footnotetext{
${ }^{1}$ See J. Tischner, Filozofia dramatu, pp. 171-172.

${ }^{2}$ See J. Tischner, Filozofia dramatu, p. 174.

${ }^{3}$ See J. Tischner, Spowiedź rewolucjonisty ... , pp. 146-147.

${ }^{4}$ See J. Tischner, Filozofia dramatu, pp. 167-169.

${ }^{5}$ J. Tischner, Filozofia dramatu, p. 161.

${ }^{6}$ J. Tischner, Krótki przewodnik ..., p. 129.

${ }^{7}$ See Z. Dymarski, Dwugłos..., p. 101.
} 
dialogue - the story is in between the two brothers, we are in the middle of observing evil which spreads ${ }^{1}$ - wants to change the reality, but the Inquisitor can also speak the truth in the sense that he lures and deceives others into proving his point, so he can prove the reality of his words. Tischner tells us that the proper talk of the Grand Inquisitor does not have many threats, at the beginning you see only a lot of promises. But that is so only on the surface of the text. The main thread is present as a heavy cloud, above all the spiritual realm of those who are being enslaved. ${ }^{2}$ The trick is to let the people become slaves by their own will ${ }^{3}$.

Whether or not evil is real, or how is it real - i.e. what the mystery of evil is - matters not in Ivan's story. What matters is the content of the conversation itself $^{4}$. What is important is that the Grand Inquisitor finally feels the need to speak before his captive, Jesus Christ. Tischner adds something more to that: It is not true that between the absolute power and its subjects there is no dialogue. The dialogue is there, only that this is the dialogue of interrogation. ${ }^{5}$ The Grand Inquisitor says that bread is more important to people than freedom, so Tischner explains: Here we see the power: bread in exchange for freedom. Against this background, the kingdom of heaven presents itself: freedom even without bread. ${ }^{6} \mathrm{We}$ see the truth of a man who has the power and takes action into his own hands. What he is telling will come true if he has enough will-power for it to happen. And he has the will-power as well as the knowledge. Tischner writes that sometimes it seems that one needs to know more to lie than to speak the truth ${ }^{7}$. That would normally be a problem, but not in this case. The Grand Inquisitor is talking about himself and other priests who will lie to people so that they can rule over them in the name of Christ, and that lie will become reality insofar as the people will believe it. The tactic is to tell them that human nature is weak, show them mercy by letting them sin, and to let them know that he who rules over them does so unwillingly and with great suffering so that they will feel ashamed to even think for a moment about rebellion; they will feel the necessity of kneeling before the Grand Inquisitor, but will also require others to do the same, and they will kill those who do not play along ${ }^{8}$. Tischner explains: The Inquisitor will never risk his life because there is nowhere to be found an enemy worthy of him. The slaves will do that for him. ${ }^{9}$

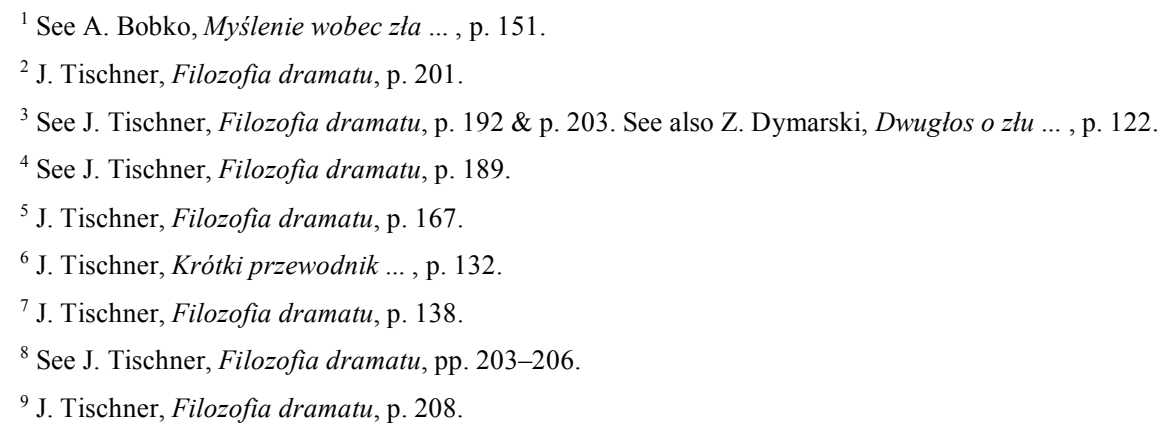


The Grand Inquisitor's power is symbolized by the fact that he answers his questions, even though it is Christ, his prisoner, who is being asked. Thus, Christ does not allow himself an opportunity to ask his questions, even though the position of the one who asks questions is privileged, and the situation makes one stand above the other ${ }^{1}$. If we look at this like that, we see that the Grand Inquisitor is above and beyond Raskolnikov, who constantly needed to worry if he did not say too much or too little, if he is not behaving suspiciously, if the enemy is planning his next move or not ${ }^{2}$. The Grand Inquisitor fears none of that. He does not need to ask: [w] hat would I do in your place and what would you do in my place $?^{3}$ And this is the reason why that is so:

Slavery is [here] a product of the masters who never had to risk their lives. Dostoyevsky's master is not a hero of the war, but a genius of illusion. The character of the Grand Inquisitor is a symbol of the champion of delusion [mistrz utudy]. The reign of the Inquisitor who is unable to risk his life must go deeper than a parental-chivalrous kind of reign because it is not only about a slave who is working instead of his lord and for his lord, but also about a slave who will gladly die for his lord if the situation requires that. ${ }^{4}$

At least Ivan's story ends with Christ's kiss as the only answer which burns the cold heart of the Grand Inquisitor, letting Christ free, even though the old man was about to kill Him. Alyosha was not convinced by Ivan's story, by that portrait of Christ. That ending would fit the narrative of Tischner (one needs to want to be good). And yet here, when Tischner recalls Brothers Karamazov, he does not mention that ending. The reader is left with the dark image of the persuader. Once again, Tischner does not want us to believe in an easy victory over evil. We are left with the impression of the Grand Inquisitor who will never change his mind and who will keep on deceiving people. The Grand Inquisitor was not as powerful as he thought himself to be, but that would ruin Tischner's description of evil. Instead, Tischner's conclusion of that story is this: [u]p until now the truth had the power over the act of thinking, but it did not bring people happiness. From now on thinking will have absolute power over the truth. ${ }^{5}$ What Tischner is getting at is that people often do not want freedom ${ }^{6}$. There is no possibility of overcoming evil if that is the norm. These examples of evil show us - and it is we who need to consider if there is some truth in it - that often the will towards action is what differentiates evil from the non-evil. If the battle was a game of chess, then,

\footnotetext{
${ }^{1}$ See J. Tischner, Filozofia dramatu, p. 97.

${ }^{2}$ See J. Tischner, Filozofia dramatu, pp. 145-146.

${ }^{3}$ J. Tischner, Filozofia dramatu, p. 152.

${ }^{4}$ J. Tischner, Filozofia dramatu, p. 202.

${ }^{5}$ J. Tischner, Filozofia dramatu, p. 160.

${ }^{6}$ See J. Tischner, Krótki przewodnik ... , p. 132.
} 
contrary to what one might expect, evil is playing as the whites, and so the other side is restricted to reacting. Tischner informs us that being oriented only towards describing the truth, it [i.e. the descriptive reason] awakens too late to stand up to the practice of politics. It opens its eyes when the work is already done, and then it becomes captivated by its charm. ${ }^{1}$ Even if it is not captivated, the truth is that there can be no heroism until there is fire on the roof. To simply assume that Cain is potentially good, i.e. that he might have a change of heart at any moment, means to allow me to be slaughtered by him. There is no problem if I turn my other cheek ... that is, if only my life is on the line. The history of the $20^{\text {th }}$ century can quickly change such a view. No one could save Abel from the wrath of Cain - Abel himself was unwilling, though technically not unable, to do anything - and no one could save the people from the justice of Bolshevism, not when they allowed Bolshevism to spread years before Lenin took power ${ }^{2}$. What is needed to secure the dignity of a man is to affirm that he is - whether a victim or a perpetrator - authentically free and that one day he will be judged accordingly. We could even, perhaps, agree that it would be easier if there was no freedom - easier for people like Srubov - but first and foremost we must point out to the anxiety that lies deep as the condition to talk about such topics. There is a need to talk about freedom, just as there is a need to talk about God ${ }^{3}$.

\section{God as the missing topic of a man}

In order to view properly the condition in which a man takes action - i.e. to view the scene of his freedom - one ought to see the man in the light of $\mathrm{God}^{4}$. That will not come easily nor will it be accessible from the very start, firstly because we would need to demand some kind of mystical moment for that to happen, and secondly because we are not given the task of finding some kind of Plotinus's One. While searching for God we are always limited by the world inhabited by people, which is here for us to explore ${ }^{5}$. Tischner explains it like this:

When we talk about a man, we use a threefold language, and we use a similar language when we talk about God. Firstly it is the language of ontology, which tells us that "something" is, and "what" it is. Then it is the language from the sphere of the theory of consciousness, through which we try to describe what "someone" knows, what he feels, what he loves, what he hates. And finally, the language of

\footnotetext{
${ }^{1}$ J. Tischner, Filozofia dramatu, p. 162.

${ }^{2}$ See A. Bobko, Myślenie wobec zła ..., p. 138.

${ }^{3}$ See J. Tischner, Spór o istnienie czlowieka, pp. 321-322.

${ }^{4}$ See I. Marszałek, Józef Tischner i filozoficzne koncepcje zła ..., p. 146.

${ }^{5}$ See J. Tischner, Spór o istnienie czlowieka, pp. 325-327.
} 
agathology ${ }^{[1]}$, which tries to tell us about the mystery of good and evil. Every one of those languages possesses at least one word with which it wants to hit the spot of "the essence of its affair". The language of ontology tells us that God is the highest beingful [bytowy] perfection, while a man some beingful imperfection. The language of consciousness tells us that God is Love, while a man a mixture of love and hate. The language of agathology tells us that God is the Good, while a man a being prone to evil. ${ }^{2}$

To be a mixture of love and hate is not the same as being prone to evil. The latter is more demanding, it begs for concrete questions and examples examples like Ivan and Alyosha. To be prone to evil is to be prone to what is tempting. At the same time, evil does not need to be very expressive. It works most efficiently when it lurks in the shadows, i.e. it starts from little steps. That way it truly has the initiative, while someone who appears to be good can only react to the harm that has already been done, since he cannot or should not accuse before an action has been done; he follows the presumption of innocence. This presumption, which by itself is correct, is that which can always be exploited. So the evil one has not only the possibility to be parasitic by living from the spoils of the work of others, but also by appealing to the values which he uses only instrumentally. The awareness of this surreptitiousness is, in fact, alarming ${ }^{3}$. And this surreptitiousness, this mixture of will and reason - many motives and fears concentrated together behind the veil of subjectivity which erects simple, objective disasters, e.g. Auschwitz and Kolyma - is exactly the one thing, the one fact of this world before which we sometimes feel helpless. This is the feeling of a disaster that seems to come out of nowhere because the stage of preparation came into existence unnoticed. It came unnoticed because morality became something relative; the reason for that was the tension within the religious communities, which originated with the religious wars of the early modernity.

Now everything seems to be relative and there seems to be no freedom on the one hand, there are the undisputed facts of physics and biology, on the other hand, the chaos of multiple opinions concerning the topics of the humanities, and virtually nothing in between or above that division. Or, to put it another way, we know more and more about that which does not make room for the question of what to do in any given situation. It is - if we strip it down to one word - a lie, but such a powerful and colourful and over-expressed lie that only God can handle, and before His intervention we can only fight for

\footnotetext{
${ }^{1}$ Agathology as that which is more than axiology, because here the I itself is the value, where the I itself should be understood primarily from the perspective of Husserl's philosophy. See A. Wesołowska, Fenomenologia i agatologia, p. 84. In the 70s Tischner was oriented towards axiology, and earlier on he started his independent philosophical journey from Husserl, so this explanation of agathology seems to be the most important one.

${ }^{2}$ J. Tischner, Spór o istnienie czlowieka, p. 325.

${ }^{3}$ See J. Tischner, Spór o istnienie człowieka, p. 345
} 
one more cause, brought upon by one more misunderstanding that kicked the ball of retaliation. So Tischner concludes: Can the deceitful freedom free itself from its lie? Unfortunately, no. Freedom's self-deception cannot, by itself, free itself from the untruth. Only God can cast a light into the darkness of such deceit. ${ }^{1}$

So there is no divine intervention, no second coming of Christ. Not at the moment. Still, God can return to our lives. Now here comes Tischner's agathology, which tries to break that deadlock by a simple suggestion that it is not only God Himself who is transcendent. It is also the case that the Good that comes from Him, but is present in the actions of His faithful children ${ }^{2}$, i.e. Sanctum, is something which seems to be not from this world when we experience $i^{3}$, like a light shining despite the sea of sin, despite, but not really against the sin, not as its mechanical reaction, not as something which would bring to mind Manichaeism ${ }^{4}$. As Bobko puts it: [i]n Tischner's intuition freedom is the means to show the freedom that is hidden within the other ${ }^{5}$. We usually only catch a glimpse of that which is good in the rigid, prone to conflict with each other values that we represent ${ }^{6}$. It is difficult, but perhaps important, to talk about what is good among values. Solidarity is one of them, but there are many more, and all of them are ready to be defined within the context of other values. This is how we grasp the good as Sacrum.

So Sacrum might sometimes give us confusion because it is presented within the abundance of values that we ought to follow, while Sanctum is that which is simple in its intuitive presentation - perhaps as a face or a gesture though still difficult to grasp in mind. It is the Good that is being noticed through the encounter with a man, not through the philosophical considerations about values. That which is Sacrum and which is bounded by values demands, while Sanctum only occurs ${ }^{7}$. Tischner explains: At one point Abraham discovers that God is first and foremost the highest Good, while only secondarily the Sacrum. ${ }^{8}$ This situation in which we live, where Sanctum seems almost unreachable, Sanctum which was so quickly taken away from people in Ivan's story, goes far back in time and so it cannot be overcome by destroying one shape which evil took for itself, like the religious wars, for example ${ }^{9}$. And thus: the question concerning God is an essential question for

\footnotetext{
${ }^{1}$ J. Tischner, Spór o istnienie człowieka, p. 347.

${ }^{2}$ See Z. Dymarski, Dwugłos o złu ... , p. 75.

${ }^{3}$ See G. Marcel, The Mystery of Being, p. 46.

${ }^{4}$ See J. Tischner, Spór o istnienie człowieka, p. 286.

${ }^{5}$ A. Bobko, Myślenie wobec zła ..., p. 217.

${ }^{6}$ See Z. Dymarski, Dwugłos o złu ..., p. 42 \& p. 45.

${ }^{7}$ See M. Drwięga, Solidarność wstrząśniętych ..., pp. 66-69 \& A. Bobko, Myślenie wobec zła ... , pp. 193-196, p. 201 \& pp. 211-212.

${ }^{8}$ J. Tischner, Rekolekcje paryskie, p. 243.

${ }^{9}$ Besides, should we think about destroying or opposing, we would in fact miss the point of Sanctum. That which is good shines by the example.
} 
a man as a dramatic creature. It itself is the drama. ${ }^{1}$ The question concerning God, whatever that question might be, decides it all ${ }^{2}$. The question could be something like this: what should a man do when God does not intervene? What should he $d o$, what should be the gesture? We do not ask about a new philosophy. This is the road of Alyosha, not Ivan ${ }^{3}$.

The answer is to accept the world as the gift given by God and treat the gift accordingly ${ }^{4}$. How? Two things are important here 5 . We must remember that the world is good only if the interaction with the other is good; we must remember that our relationship with the world, with the world of the living, is mediated by the relation with the immediate other, e.g. my father, my neighbour, my teacher ${ }^{6}$. Now, thanks to that experience - thanks to that experience that I am not, like Srubov, at the center of things ${ }^{7}$ - there is a second point which is open, namely: we must treat the world, the world as a whole and every single thing in it, as the sign of that which comes after ${ }^{8}$. Tischner tells us that the Earth is a scene and the scene is for a man, but exactly in such sense as the signpost standing by the road is also for a man. Does anyone attach himself to a signpost? ${ }^{9}$ To put it more exactly:

The old theory of metaphorical imagery [metaforyka]

has led us from that which is immediate, common and known (e.g. man's goodness) to that which is distant, unknown, hard to comprehend (e.g. God's Goodness). The hermeneutic thinking points to our crossing towards the other direction: entities are metaphors, a metaphor is something that is immediate, something common, something tangible. A metaphor of what? A metaphor of that which truly is beyond the entities. The existence that is experienced by us, all the sphere of our physis, is in its very nature a quasiexistence. ${ }^{10}$

Of course, the difficulty lies in putting that way of thinking into action, in the little choices that we made. This hope - because it really is an elaborated expression of hope - will not solve all the problems, but it will make a condition for harmony between those who struggle to eat, and those who are

\footnotetext{
${ }^{1}$ J. Tischner, Filozofia dramatu, p. 21.

${ }^{2}$ See J. Tischner, Filozofia dramatu, p. 21, p. 49 \& p. 59.

${ }^{3}$ See B. Treanor, Aspects of Alterity, p. 56.

${ }^{4}$ See J. Tischner, Spór o istnienie człowieka, p. 348 \& J. Tischner, Etyka Solidarności, pp. 83-84.

${ }^{5}$ See. Ł. Kołoczek, Struktura uczestnictwa ..., p. 54.

${ }^{6}$ See W. Glinkowski, Problem sceny ..., p. 76 \& A. Bobko, Myślenie wobec zła ..., pp. 194-195.

${ }^{7}$ See G. Marcel, Homo Viator, p. 159.

${ }^{8}$ See G. Marcel, Homo Viator, p. 226.

${ }^{9}$ J. Tischner, Filozofia dramatu, p. 230.

${ }^{10} \mathrm{~J}$. Tischner, Myślenie wedlug, p. 504. It is also worth noting that one must use a language that expresses people in a unique way so that they will not be confused with mere things. See Z. Dymarski, Dwugłos o złu ...,
} pp. 11-12. 
constantly hungry ${ }^{1}$. It will make possible the experience of the Good, something much more important than its theory ${ }^{2}$.

When we look at this in such a way, then the story of a husbandman, even if that was just a myth, i.e. even if the world was always broken ${ }^{3}$, could be seen as the idea which needs to be told. This image is what prevents the talk about common, deceitful freedom from becoming abstract moralization, and it plays the role of a reminder that not everything which is buried in the past deserves condemnation. At the same time, it gives us the image of the Good as something closer to our expectations when compared to a hypothetical situation in which Tischner would simply say that the Good is beyond this world. A single individual is not someone who can unfold the thick web of lies that was being created through centuries. Yet why should a philosopher not use all the stories that we were told to give us direction? The stories that are being told are changing in such a way that one has to notice that they carry all the truth about worries and pain, and these are not the same throughout the centuries. For instance, could a history of Srubov be told in Ancient Greece? These are the shadows from which we can find the light.

One example would be Tischner telling us that the biblical Abraham knew about the Promised Land already when he had put his gaze on the land of exile. Tischner explains: Abraham's desire had two aspects to it: the discovery of the Promised Land went in a close relationship with the discovery of the land of exile. One could not be separated from the other. ${ }^{4}$ Having this quote in mind, the already mentioned examples of evil can indeed point us towards the Good, even if it seems that there is no such thing. That which is important is appreciated when it is out of reach. Art can give us this wisdom with no need for a man to stumble upon the situation of no return. Tischner points that out with the example of the sign that Dante Alighieri sees in hell. It is people in hell who must abandon hope, but the sign gives hope to those who read The Divine Comedy ${ }^{5}$.

Beyond one wall of webs always hangs another, and a new one is being created $^{6}$. One is left with the uncomfortable feeling that something is seriously wrong, even though the sensation does not come from the simple observation of aging and death. So Tischner, in his own way, also writes about the Marcelian broken world, with a great emphasis on the fact that people are being blind to this wound, or, looking at it from the other direction, blind to the primordial experience of $\operatorname{good}^{7}:[\mathrm{t}]$ he primordial experience of good is the

\footnotetext{
${ }^{1}$ See I. Marszałek, Józef Tischner i filozoficzne koncepcje zła ..., pp. 242-243.

${ }^{2}$ See J. Tischner, Filozofia dramatu, p. 113. See also I. Marszałek, Józef Tischner i filozoficzne koncepcje zła ..., p. 272 \& A. Bobko, Myślenie wobec zła ..., p. 161.

${ }^{3}$ See G. Marcel, The Mystery of Being, p. 23.

${ }^{4}$ J. Tischner, Filozofia dramatu, p. 67.

${ }^{5}$ See J. Tischner, Spór o istnienie czlowieka, p. 13.

${ }^{6}$ See J. Tischner, Spowiedź rewolucjonisty ... , pp. 105-106.

${ }^{7}$ See G. Marcel, Homo Viator, pp. 153-154.
} 
consciousness that it is so, but it should not be ${ }^{1}$. Just because that-whichshould-not-be has been - here and there, in that war or that famine suspended does not mean that the positive experience of the Good within a man will overwhelm us with joy. There is, after all, a realization within the Christian mind that to overcome the root of evil without God is impossible ${ }^{2}$. It is impossible because what might appear as the authentic Good which unities people together from their own free will shows itself as a behaviour which only could take place and sustain itself as the reaction to the evil which cannot be tolerated anymore. Tischner concludes: [t]he essence of the drama with God comes down to the fact that God is the Good, and man is a sinner. The gap that separates the Good from evil is bigger than that between infinity and finitude of being. ${ }^{3}$ If so, then this behaviour is only rarely spontaneous, remaining usually as the necessary reaction to evil, evil which is always somewhere there. I must act! is the echo of Srubov's I must be ready! Tischner puts forward that problem very clearly:

It is usually the case that the rationality of a system is rather inconspicuous. We hear a call for maintaining order only when at some corner order "breaks down". When the bread is here, people are not interested in agriculture, when the bread is missing everybody asks what happened. ${ }^{4}$

\section{Conclusion - the example of Christ}

Now the fact of the day is that, as far as we can tell, bread is always, eventually, returning to the shelves. Could it be the case that the Good triumphs only to be one day again devoured by evil ${ }^{5}$ ? There is a duty to believe otherwise, despite the seeming over-presence of evil. Perhaps evil which avoids being noticed will be less of an issue if we, too, get used to something that points above the empirical. The Grand Inquisitor could see something more when looking at a loaf of bread, and so can we. The possibility of overcoming evil, even if evil cannot be fully overcome without God's intervention, begins the topic of Christian education because the one who is free nonetheless imitates somebody. If Srubov is the role-model, evil will spread. Luckily, those times are behind us. The example can be different and the point is to give the example - one's own example or the example of Christ.

The example encourages thinking about the meaning of the example; it encourages moving beyond that which is immediate. The habit of doing so is

\footnotetext{
${ }^{1}$ T. Niezgoda, Metafora dramatu ..., p. 93.

${ }^{2}$ True, one could also see that as a good sign, because it also means that we are in the good hands - we just need to focus on trying to remain good in all the little decisions of our life, while God will eventually handle the rest. See P. Karpiński, Biblia w filozofii dramatu ... , pp. 108-109.

${ }^{3}$ J. Tischner, Spór o istnienie człowieka, pp. 194-195.

${ }^{4}$ J. Tischner, Etyka solidarności, p. 60.

${ }^{5}$ See J. Tischner, Miłość nieumiłowana, p. 16.
} 
the proof 1) of the freedom within concrete decisions, and 2) of the hope which makes our decisions possible. What seems to be crucial in opposing evil is the realization that there is always a decision to be made. Evil wants the common man to do nothing. The thing about hope is that it is always actionoriented and never satisfies itself with solitude. With evil, especially with the kind of evil that was done by Srubov, we have a caricature of that: there is $a$ semblance of building something (lunacy, in fact) and a semblance of not being alone. Before the time of awareness of it being a semblance Srubov keeps going, but the tragedy lies in the fact that he himself is responsible for prolonging that show, that he struggles exactly not to see the truth, the truth that screams with obviousness. Srubov himself should have given his scream long before he actually did.

This struggle is the mystery of evil. We cannot move beyond that in our understanding. We will not wish ourselves to have the chance to experience it. We can propose from it that evil (not a mere wrong-doing and not something that is seen as limited to one person, but, on the contrary, as that which spreads itself) is that which casts two illusions. The first is the illusion of comradery, for it must somehow begin from the absence of both opportunities without which it cannot accomplish much - therefore it needs more people and values of its own without which it cannot become fascinating - therefore it needs to tell its own stories. The second is the illusion of determinism, for it wants to use strong threads and it wants to justify itself when all is over. The evil man wants to remain himself, i.e. the self-destruction is indeed the result, but never something that is being sought with full consciousness, as long as the evil within remains. In other words: man does not sacrifice himself to evil, he merely loses himself to it. So if the self-destruction was indeed the goal from the beginning, we are dealing with someone who is being used by evil as an instrument; that which is not good is not automatically evil, and evil within a man is not something permanent. Both Srubov and Judas wanted to commit suicide from a certain point, and Srubov rightfully described himself as a squeezed lemon - though we must remember that the damage was already done, and a man becomes not reborn from the experience ... but motionless.

Now the confusion about evil - the confusion which is something serious for us - comes from the fact that those two illusions are often cast by two people who are somehow connected despite the difference in time in which they live and in the exact purpose that they serve; and yet we still speak about one evil, as we do about the evil of Communism, which was exemplified by the table-turning from Raskolnikov to the Grand Inquisitor. The fact that evil need not remain evil is something cheerful, but the observation that it usually remains stubborn is not. Since an illusion depends on the real - on Being evil is dependent, and since we, as Christians, ought not to turn our gaze away from the transcendence, the claim is that it depends on the Good. The challenge lies in not describing it in the language of ontology, for the risk is that ontology will tell us about evil - perhaps unsurprisingly - exactly nothing. It will tell us nothing about a man who is being tempted to become evil. From Tischner's perspective, this is all that can be said about evil. 


\section{Bibliography}

Anderson T., A Commentary on Gabriel Marcel's The Mystery of Being, Marquette University Press, Milkwaukee 2006.

Benefield J., The Place of God in the Thought of Gabriel Marcel, University of Canterbury Press, Christchurch 1973.

Bobko A., Myślenie wobec zła: Polityczny i religijny wymiar myślenia w filozofii Kanta i Tischnera, Instytut Myśli Józefa Tischnera, Kraków 2007.

Drwięga M., Solidarność wstrzaśniętych i solidarność z kimś i dla kogoś. Kilka uwag o roli etyki w pogladach Jana Patočki i Józefa Tischnera in: Kwartalnik Filozoficzny 46, 2018

Dymarski Z., Dwugłos o złu: Ze studiów nad myśla Józefa Tischnera i Leszka Kołakowskiego, Wydawnictwo słowo/obraz terytoria, Kraków 2008.

Glinkowski W., Problem sceny w Tischnerowskiej filozofii dramatu in: Analiza i Egzystencja 33, 2016, pp. 71-90.

Karpiński P., Biblia w filozofii dramatu ks. Józefa Tischnera in: W. Śmigiel (ed.), Język - Szkoła - Religia, Wyd. Bernardinum, Gdańsk 2018, pp. 94 122.

Kołoczek Ł., Struktura uczestnictwa w filozofii dramatu Józefa Tischnera in: Logos i Ethos 48, 2018, pp. 53-79.

Marcel G., The Mystery of Being: I. Reflection \& Mystery, transl. G. Fraser. Henry Regnery Company, Chicago 1950.

Marcel G., Homo Viator, transl. E. Craufurd, Henry Regnery Company, Chicago 1951.

Marcus P., In Search of the Spirituality: Gabriel Marcel, Psychoanalysis and the Sacred, Karnac, London 2013.

Marszałek I., Józef Tischner i filozoficzne koncepcje zła: Czy zło jest $w$ nas, czy między nami?, Wydawnictwo WAM, Kraków 2014.

Niezgoda T., Metafora dramatu $w$ filozofii dramatu Józefa Tischnera in: Kwartalnik Filozoficzny 46, 2018, pp. 73-96.

O'Malley J., The Fellowship of Being: An Essay on the Concept of Person in the Philosophy of Gabriel Marcel, Martinus Nijhoff, The Hague 1966.

Tischner J., Fenomenologia spotkania in: Analecta Cracoviensia 10, 1978, pp. 73-98.

Tischner J., Na drogach krzyżowych historii: Rekolekcje 1982, Wydział Duszpasterstwa Kurii Metropolitarnej, Kraków 1982.

Tischner J., Myślenie wedtug wartości, Wyd. Znak, Kraków 1993.

Tischner J., Miłość niemiłowana, Wyd. Znak, Kraków 1993.

Tischner J., Spór o istnienie człowieka, Wyd. Znak, Kraków 1998.

Tischner J., Etyka Solidarności oraz Homo Sovieticus, Wyd. Znak, Kraków 2005.

Tischner J., Wiara ze stuchania: Kazania starosadeckie 1980-1992, Wyd. Znak, Kraków 2009.

Tischner J., Filozofia dramatu, Wyd. Znak, Kraków 2012.

Tischner J., Rekolekcje paryskie, Wyd. Znak, Kraków 2013.

Tischner J., Spowiedź rewolucjonisty: Czytajac Fenomenologię ducha Hegla, Wyd. Znak, Kraków 2016. 
Tischner J., Krótki przewodnik po życiu: Nieznane teksty, Wyd. Znak, Kraków 2017.

Treanor B., Aspects of Alterity: Levinas, Marcel, and the Contemporary Debate, Fordham University Press, New York 2006.

Wesołowska A., Fenomenologia i agatologia in: Zeszyty Naukowe Centrum Badań im. Edyty Stein 13/14, 2015, pp. 81-88.

Wieczorek K., The Ethics of Solidarity According to Józef Tischner in: Philosophy and Canon Law 3, 2017, pp. 71-89. 